\title{
Terapia Assistida por Animais: Estratégia para Humanização do Ambiente Hospitalar
}

\author{
Batista, Maria Beatriz de Souza; Portela, Odete Teresinha; Carmagnani, Maria \\ Isabel Sampaio; Luz, Fátima Vicente Ferreira da; \\ Santos, Edson Silva dos; Borgo, Cristiane
}

Hospital São Paulo — beatrizbatista@hotmail.com

Introdução: Estudos mostram que a Terapia Assistida por Animais vem sendo utilizada em várias áreas da saúde com resultados animadores, tanto em crianças como idosos, portadores de deficiências e doenças crônicas, com melhora cognitiva, da funcionalidade, da mobilidade e no autocuidado, aumentando a sensibilidade e atenção e diminuindo os níveis de dor 2,3,4. na internação, o paciente fica distante de tudo e de todos seus significantes, em um ambiente frio e triste, além de ser submetido a procedimentos dolorosos. a equipe profissional, preocupada com o cuidado humanizado, busca estratégias que tragam aos pacientes esperança, amor e alegria, ainda que seja por um breve momento, contribuindo no enfrentamento das intervenções necessárias que podem durar dias ou até mesmo meses de internação. Objetivo: Relatar a vivência no uso da Terapia Assistida por Animais dentro de um hospital, de ensino, universitário, em São Paulo. Método: relato de experiência, com base nos depoimentos e observações de comportamentos durante as atividades lúdico-educativas desenvolvidas pela equipe do projeto Amicão. Refere-se à experiência em trabalhar com a Terapia Assistida por Animais dentro de um hospital. Resultados: como estratégia de humanização do ambiente hospitalar, principalmente nas unidades de pediatria e geriatria, há oito anos vem sendo desenvolvido um projeto institucional, que conta com um cachorro Gold para o desenvolvimento de atividades lúdico-educativas, denominado Amicão. uma equipe composta de voluntários, juntamente com o cachorro, realiza visitas regulares, todas às quartas-feiras, ás unidades de internação. ao adentrar na enfermaria, o cachorro se aproxima dos pacientes, faz poses para fotografias, momentos em que a equipe aproveita para o desenvolvimento de atividades de educação em saúde, por meio de brincadeiras. a expectativa dos pacientes e dos profissionais que já conhecem as atividades desenvolvidas pelo projeto é muito grande, todos ficam entusiasmados e sorridentes ao encontrar, pelos corredores do hospital, o cachorro conduzido pela equipe profissional. Manifestações de carinho com toque e poses para fotografia. Conclusão: a equipe multiprofissional desempenha importante papel no processo de enfrentamento dos desafios em que o paciente se depara em uma internação hospitalar. As atividades realizadas, com a participação de um cachorro, tem em vista a interação entre o cachorro, pacientes e profissionais no ambiente hospitalar, mostraram ser eficientes medidas redutoras de ansiedade, ajudando no relacionamento interpessoal entre as equipes profissionais e pacientes internados

Batista, Maria Beatriz de Souza; Portela, Odete Teresinha; Carmagnani, Maria Isabel Sampaio; Luz, Fátima Vicente Ferreira da; Santos, Edson Silva dos; Borgo, Cristiane. Terapia Assistida por Animais: Estratégia para Humanização do Ambiente Hospitalar. In: Anais do Congresso Internacional de Humanidades \& Humanização em Saúde [= Blucher Medical Proceedings, num.2, vol.1]. São Paulo: Editora Blucher, 2014. ISSN 2357-7282

DOI 10.5151/medpro-cihhs-10503 